\title{
Health and psychosocial effects of flexible working hours
}

\author{
Daniela Janssen and Friedhelm Nachreiner
}

Carl von O ssietzky Universitaet O Idenburg. Department of Psychology. Industrial and O rganizational Psychology Unit. Oldenburg, Germany

\section{Keywords}

Work hours, psychology. Work hours, physiology. Occupational health. Questionnaires. Research. Internet. Working conditions.

\section{Descritores}

Jornada de trabalho, fisiologia. Jornada de trabalho, psicologia. Saúde ocupacional. Questionários. Pesquisa. Internet. Condições de trabalho.

\section{Abstract}

\section{Objective}

To examine whether any impairments in health and social lives can be found under different kinds of flexible working hours, and whether such effects are related to specific characteristics of these working hours.

\section{Methods}

Two studies - a company based survey $(\mathrm{N}=660)$ and an internet survey $(\mathrm{N}=528)$ have been conducted. The first one was a questionnaire study (paper and pencil) on employees working under some 'typical' kinds of different flexible working time arrangements in different companies and different occupational fields (health care, manufacturing, retail, administration, call centres). The second study was an internetbased survey, using an adaptation of the questionnaire from the first study.

\section{Results}

The results of both studies consistently show that high variability of working hours is associated with increased impairments in health and well-being and this is especially true if this variability is company controlled. These effects are less pronounced if variability is self-controlled; however, autonomy does not compensate the effects of variability.

\section{Conclusions}

Recommendations for an appropriate design of flexible working hours should be developed in order to minimize any impairing effects on health and psychosocial wellbeing; these recommendations should include - besides allowing for discretion in controlling one's (flexible) working hours - that variability in flexible working hours should be kept low (or at least moderate), even if this variability is self-controlled.

\section{Resumo}

\section{Objetivo}

Investigar se ocorre prejuízo à saúde e à vida social com diferentes tipos de horas de trabalho flexíveis e se há relação entre estes efeitos e características específicas das horas de trabalho.

\section{Métodos}

Foram realizados dois estudos, uma pesquisa em uma empresa $(N=660)$ e outra pela Internet $(N=528)$. O primeiro estudo consistiu de um questionário (papel e lápis) aplicado a funcionários sujeitos a diferentes ajustes "típicos" de horas de

Correspondence to:

Daniela Janssen Presented at the XVI International Symposium on N ight and Shiftwork, N ovember 2003. Santos, SP, Brazil. Received on 15/3/2004. Approved on 27/9/2004

Universitaet Oldenburg

Institut fuer Psychologie

Abt. Arbeits- und Organisationspsychologie

D-26111 Oldenburg, Germany

E-mail: daniela.janssen@uni-oldenburg.de 
trabalho flexíveis em empresas e áreas ocupacionais diversas (área da saúde, fábrica, comércio varejista, administração, serviços de central telefônica). O segundo estudo consistiu em um levantamento pela Internet, usando-se uma versão adaptada do questionário do primeiro estudo.

\section{Resultados}

Os resultados de ambos os estudos demonstraram de modo compatível que a alta variabilidade das horas de trabalho está associada a um maior prejuízo da saúde e do bem-estar, sobretudo se esta variabilidade é controlada pela empresa. Os efeitos são menos acentuados se a variabilidade é autocontrolada; a autonomia, no entanto, não contrabalança os efeitos da variabilidade.

Conclusões

Devem ser feitas sugestões para um planejamento adequado de horas de trabalho flexíveis para minimizar os efeitos prejudiciais à saúde e ao bem-estar psicossocial. Além de permitir o uso de um critério pessoal para o controle de horas de trabalho (flexiveis), a variabilidade das horas de trabalho flexíveis deve ser pequena (ou, no mínimo, moderada), mesmo se ela for autocontrolada.

\section{INTRODUCTION}

Innovative working time arrangements are currently regarded as some of the most important elements in the (re-)organisation of work. Politicians and employers continue to emphasise the need for more flexibility, and especially for flexible working hours in order to cope with global competition. ${ }^{15}$ The question, however, is what implementing 'flexible working hours' really means. The first problem is the lack of a suitable and generally accepted definition of flexible working hours. ${ }^{4,13,16}$ Some people go so far as to classify every kind of working hours that deviate from 'normal' working hours as flexible working hours, thus including sometimes very rigid systems like regular shift work or certain kinds of part time work. The second problem is that there is a complete lack of reliable and valid empirical evidence about the effects of flexible working hours on employees' health and psychosocial wellbeing. ${ }^{4}$ Especially well controlled and comparative studies across different kinds of flexible working hours are completely missing and thus evidence based recommendations for the design of flexible working hours arrangements cannot be found. Not discriminating between different forms of flexible or deviating work hours further blurs the perspective, because mixing up different forms of interventions (e.g. introducing night work vs. part time work) will most probably not result in the same or at least consistent effects. Combining both the definitions and the effects problem very soon makes clear that the cry for extending flexible working hours is a cry for a large scale but loosely described intervention with completely unknown effects. From an ergonomic point of view this is completely unacceptable, since one should know, or at least have an idea of the risks associated with any such intervention.

This is of special importance in the design of work- ing hours since for some other kinds of working time arrangement, e.g. shift work, it is well documented ${ }^{2,3,12}$ that they do represent a special risk to health and psychosocial well-being, which is also true for extended working hours, ${ }^{14}$ and both might be relevant in the context of flexible working hours - if flexibility is associated with variability in the chronometry (e.g. by extending one's working hours) and the chronology of working hours (e.g. when deciding about the temporal position of on- and off-duty hours).

Flexible working hours are usually requested in the context of being able to adapt working hours to the demands at hand, either demands of the company or demands of the employee. Flexible working hours thus inherently bear the meaning of adaptation and change. Talking about flexible working hours thus means to start from the assumption that working hours are variable and changeable, in duration and/or in position, and that there is a choice which can be influenced by employees, employers, or both. Therefore the SALTSA group on flexible working hours has adopted the following definition: Flexible Working Hours involve a continuous choice on behalf of employers, employees or both, regarding the amount (chronometry) and the temporal distribution (chronology) of working hours. ${ }^{4}$

Against this background of blurred concepts, unknown effects and the cry for the extension of flexible working hours a research project has been started in Germany to examine the prevalence of flexible working hours and their implications on health and well being, testing the following research hypotheses:

1. Besides the advantages, which these kinds of working time arrangements may have for companies and employees, flexible working hours may also have impairing effects on health and on psychosocial well-being of employees. 
2. Different systems of flexible working hours may have different effects on health and psychosocial well-being of the employees working under such systems.

These hypotheses are based on the following theoretical considerations: at least some kinds of flexible working hours show some structural similarities with shift work, e.g. deviations from normal working hours, irregularities or variability in the diurnal position of working hours, which result in a desynchronization with 'normal' temporal structures of behaviour, which in turn might thus result in impairments comparable to those found in shift work, comparable in the form of the impairment, but most probably less in extent, since the amount of the desynchronization under flexible working hours should be less than that under shift work, unless flexible working hours include night and shift work.

There is some empirical evidence showing that different kinds of shift systems lead to different effects, differing again in form and extent of the impairments. ${ }^{9,10}$ It is thus consistent to assume that different kinds of flexible working hours will also lead to different effects, with effects differing in kind and extent, depending on the specific characteristics of the arrangement of flexible working hours.

Another problem with flexible working hours could be that flexible working hours may lead to accumulations of working hours, based on decisions either by the employer or the employee, leading to increased variability in the number of daily or weekly working hours and to increased work strain during work periods of increased length (which might not be compensated adequately during rest periods). This also could lead to impairments in health and well being and thus should be observed in designing flexible hours of work systems.

Results on the prevalence of flexible hours in Germany have been presented elsewhere ${ }^{5,13}$ so this paper will be restricted to the effects of flexible working hours on health and well-being.

\section{METHODS}

In order to address these research questions two studies have been conducted: the first one was a questionnaire study (paper and pencil) on employees working under some 'typical' kinds of different flexible working time arrangements in different companies and different occupational fields (health care, manufacturing, retail, administration, call centres). The intention to compare employees working in compara- ble jobs, under comparable working conditions, etc but differing in flexible vs. fixed hours of work had to be given up because jobs were either done under flexible working hours or fixed working hours in the same company, but not under both, and comparing jobs across different companies with different working conditions would have resulted in a confounding of effects. So the study was aimed at finding differences in impairments depending on different types of flexible working hours.

This seemed appropriate because if specific characteristics could be found which could explain differences in impairments this would imply a falsification of the hypothesis that flexible working hours do not impose any risk to health and well being and at the same time indicate the characteristics or conditions to be observed in designing and implementing flexible working hours.

The second study was an internet based survey, using an adaptation of the questionnaire from the first study. This was done because it was not possible to get the co-operation of companies with purely company controlled flexible working hours. So these kinds of working time arrangements were not adequately represented in the first survey, resulting most probably in a severely biased sample with severely biased results. This seemed not acceptable because it would have excluded/ underrepresented some of the types of flexible working hours which industries and services are calling for when requesting the extension of flexible working hours for reasons of economic competition.

By offering participation in the internet study independent of any management consent it was hoped to compensate for the supposed bias of the company based survey. The questionnaire was presented in German, offering participation to German speaking employees.

There was absolutely no control over who participated in the internet survey, the only control applied was a check for multiple responses from the same respondent within a short time interval by comparing and eliminating identical data sets. The information concerning the survey was spread via newspapers and some internet links. It was clear from the beginning that the resulting sample would not at all be representative but most probably also biased, since it could be expected that those with problems with their flexible working hours would be more inclined to fill in the questionnaire than those who were completely happy with them. On the other hand this could compensate for the positively biased sample from the company based survey, resulting in a rather fair composition of the total sample. By ana- 
lysing the data separately any such bias should become evident.

A specially designed standardized questionnaire was used for these surveys, based on experience from shift work research with regard to physical and psychosocial impairments, containing questions about:

- demographic variables (gender, age, and family situation)

- hours of work (e.g. number of contractual working hours, overtime, possibilities of influencing/ controlling one's working hours) as independent variables

- satisfaction with a number of working conditions and especially working hours

- frequencies of 18 health complaints, (most of them found to be sensitive in earlier shift work research, involving sleep related problems, digestive problems, psycho-vegetative problems, musculoskeletal problems, etc., using a format like 'how often do you suffer from sleeping problems', with response scales ranging from 'never' to 'always'), smoking habits, sleeping habits

- family life, social and leisure activities, and satisfaction with these aspects (using mostly Likert-type response scales)

- finally, at the end of the questionnaire, a diary by which respondents were requested to provide information about their (factual) daily working hours over a period of four weeks. This was done because results from the preceding interviews with the management and the workers councils of the companies involved showed that it was nearly impossible to get consistent information about the specific, both agreed and especially actual, arrangements of flexible working hours in most companies.

For the company based study 2,159 questionnaires have been distributed to 17 companies which were willing to participate in this research and which distributed them to their employees (mostly via the workers councils). 660 of these were returned in a form suitable for the intended analyses, yielding a response rate of $31 \%$. Considering that a lot of companies refused to take part in the research, mostly those with purely company controlled flexibility, and the rather low response rate the sample cannot be considered representative, as usual in such kind of studies. For the internet survey no response rate can be given of course.
Table 1 gives an overview over some of the demographic characteristics for both samples, showing that both samples are definitely not derived from the same population. While age is not different for both samples, covering the whole range of employment in Germany, gender is $(\mathrm{p}<.001)$, with a stronger participation of male respondents in the internet survey than in the company based study. Because valid data on the prevalence of flexible working hours in Germany are not available there is no possibility of estimating any representativity for both samples. From the data available, however, it would seem that both samples are not representative. Since the access to the internet study was free and independent of the company and questions concerning which company the respondents worked for have not been asked there is possibility to state from how many and what kind of companies the respondents of the internet survey came from. Information is only available on the sector and some characteristics of the company the respondents work for. These data again make clear that both samples come from different populations, thus allowing for a test of the same hypotheses in two different samples, and thus for a cross validation of the results.

Based on the items concerning working hours it was possible to distinguish different types of flexibility. As the definition of flexible working hours adopted above implies important dimensions or factors of the flexibility of working hours are their variability in duration, their variability in the chronological position and the influence of the employees and/or the employers on controlling working hours. Respondents were therefore grouped into groups with either no, low or high variability in both duration and position of their working hours (in order to get pure types only) and according to their (perceived) influence in controlling their working hours. Since any variation due to the variability introduced by shift work was considered as a confounding effect for the intended analyses, only those respondents were use for the analyses who did not work regular, irregular or flexible forms of shift work. Further analyses will have to show whether the effects of flexibility will hold for flexible shift work as well. Another reason to limit the analyses to non shift workers was the restricted number of respondents when breaking them down into separate categories.

This resulted in 3 (variability) by 2 (influence) $=6$

Table 1 - Study samples.

\begin{tabular}{lcccc}
\hline Study & Companies & $\mathrm{N}$ & Mean age & Gender \\
\hline Company based & 17 & 660 & 37 years & $66 \%$ female \\
Internet based & $?$ & 528 & $\begin{array}{c}(17-63 \text { years }) \\
40 \text { years }\end{array}$ & $\begin{array}{c}34 \% \text { male } \\
\text { (18-64 years) }\end{array}$ \\
\hline
\end{tabular}


Table 2 - Number of respondents in each of the six flexibility groups.

\begin{tabular}{|c|c|c|c|c|c|c|}
\hline \multirow[t]{2}{*}{ Study } & \multirow[b]{2}{*}{ S- V- I+ } & \multicolumn{4}{|c|}{ Type of flexibility } & \multirow[b]{2}{*}{ S- V++ I- } \\
\hline & & S- V- I- & $\mathrm{S}-\mathrm{V}+\mathrm{I}+$ & S- V+ I- & S- V++ I+ & \\
\hline $\begin{array}{l}\text { Company based } \\
\text { Internet based }\end{array}$ & $\begin{array}{l}38 \\
28 \\
\end{array}$ & $\begin{array}{l}87 \\
25 \\
\end{array}$ & $\begin{array}{c}69 \\
113 \\
\end{array}$ & $\begin{array}{l}12 \\
15 \\
\end{array}$ & $\begin{array}{c}3 \\
17 \\
\end{array}$ & $\begin{array}{c}3 \\
33 \\
\end{array}$ \\
\hline
\end{tabular}

types of flexible working hours arrangements, with cell frequencies as shown in Table 2 . This selection makes use of $32 \%$ of the total sample of the company based study and of $43 \%$ of the data from the internet sample. As can be seen from Table 2 the distribution of respondents across these 6 types of flexibility is different for both samples $(\mathrm{p}<.001)$, showing that the internet study was more successful in recruiting respondents with company controlled flexibility, as intended. Whereas in the company based study $59 \%$ showed no variability in their flexible working hours, this is the case for only $28 \%$ of the internet sample. From the remaining groups with moderate to high variability only $7 \%$ were company controlled in the company based survey whereas this is true for $21 \%$ in the internet study. Both distributions are far from being as balanced as one would have preferred for the analysis, but the results will have to show whether any significant effects or at least trends can be found.

The 6 types of flexibility were used as the independent variable in oneway ANOVAs to test for differences between types of flexibility (using SPSS 10.0 to 11.5 for all statistical analyses). This has been done in order to be able to perform some robust tests on the differences between the types or the combinations of independent variables, given the differences in cell frequencies. Dependent variables in this step of the analysis were the individual items on health and psychosocial well-being, e.g. on satisfaction, health complaints, leisure and family activities. In order to control for possible confounding effects of other variables like gender, age, or some other relevant working conditions analyses of covariance have been conducted.

In a second step factor scores resulting from factor analyses of the sets of items of the dependent variables were used as dependent variables in ANOVAs in order to reduce the great number of dependent variables to a smaller number of factor scores, e.g. for leisure activities, family life, or health, and to use their common variance only. Factor scores could be calculated for psycho-vegetative complaints (including sleeping problems), fatigue or exhaustion, digestive complaints, respiratory and allergic complaints in the health area, and for family relations and social activities in the psychosocial area.

In the final step two-factorial MANOVAs were used with influence (I) and variability (V) as independent variables and the factor scores from the factor analyses as the dependent variables in order to separately test for main and interaction effects of variability and influence and to avoid multiple testing.

\section{RESU LTS}

Due to the great number of dependent variables and the two samples only selected, but typical results will be presented here. A full account of the results (in German) can be found elsewhere. ${ }^{11}$

Results of both studies clearly show that both variability of working hours and the influence, which employees have in controlling their working hours affect their health, well being and social behaviour. For both studies consistently both significant $(\mathrm{p}<.05)$ main effects and in some cases also significant interaction effects for variability and influence have been found in the MANOVAs (for a detailed presentation see $^{11}$ ), indicating that there is a general trend in these results: increased impairments are associated with high variability and a lack of influence over one's working hours. For the company based study there is an increase in impairments with increasing variability, whereas in the internet study there is a contrast only between high variability on the one hand and low and no variability on the other hand, but not consistently between low and no variability. This applies to health impairments as well as to satisfaction with family and social life. So both areas of well being, physical and psychosocial are affected in the same manner by the flexibility of working hours, i.e. by their variability and the employees' autonomy in deciding about their working hours.

Figures 1 and 2 illustrate this pattern of results for two selected typical examples from both domains: sleeping problems and the effect of flexible working hours on leisure time. Figure 1 shows the frequency of sleeping problems for each of the 6 types of flexible working hours in both studies. As can be seen from Figure 1 there are obvious differences in reported frequencies of sleeping problems $\left(\mathrm{F}_{5,194}=2.85, \mathrm{p}=.17\right.$, company based; $\mathrm{F}_{5,221}=2.55, \mathrm{p}=.029$ internet based). In both studies the highest frequencies of sleeping problems have been reported by respondents with highly variable working hours and lack of control 


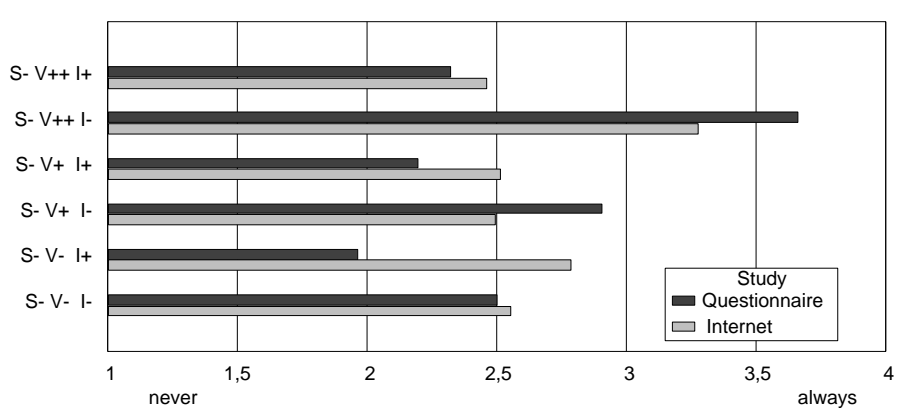

$\mathrm{S}=$ Shift work: $\mathrm{S}-=$ non shift workers [S+ = shift workers, not included here]

$\mathrm{V}=$ level of variability: $\mathrm{V}-=$ no variability; $\mathrm{V}+=$ low variability $\mathrm{V}++=$ high variability

I = employee influence: $I-$ = no employee influence; $I+=$ =mployee influence

Figure 1 - Frequency of sleeping problems by type of flexible working hours.

over their working hours. For the company based study the amount of sleeping problems decreases both with working hours becoming more regular and with a gain in autonomy $(\mathrm{I}+)$. Both factors here are clearly additive, so the lowest amount of sleeping problems has been found with those respondents who are in control of their regular working hours. In the internet study again the highest frequency of sleeping problems has been found with those respondents with highly variable, uncontrollable working hours, and less complaints from those who are able to influence their highly variable hours, who show the same extent of impairment as the other types with no (significant) differences between them. It would seem then that an increase from no to low variability is not associated with an increase in sleeping problems in the internet study whereas this is the case in the company based study.

Figure 2 shows the perceived effects of one's working hours on one's leisure time as an example for psychosocial impairments. Again there are significant differences between types of flexibility in both studies $\left(\mathrm{F}_{5,203}=3.80, \mathrm{p}=.003\right.$, company based; $\mathrm{F}_{5,223}=26.53$, $\mathrm{p}<.001$, internet based), and again the highest impairments have been found in the group with high variability and low autonomy, in both studies, and for both surveys the least impairment has been observed under employee controlled regular hours. It is obvious that a lack of autonomy is associated with increased reported impairments in both studies, whereas for variability the important difference seems to be the one between high variability on the one hand and low and no variability on the other hand. And whereas in the internet study high variability seems to be compensated by employees' control this does not happen in the company based survey; here the impairment is clearly higher than that in all conditions with less variability. In this case autono- mously controlled high variability is still associated with increased impairment.

Controlling for confounding variables, e.g. gender, age, or some of the working conditions, by means of ANCOVAs resulted in significant effects for some of these variables, resulting in different estimates of the means, but not in changes in the pattern of the results. So for all analysed subgroups the results were comparable in structure, indicating that the effects of variability and autonomy were consistent and comparable across all groups/conditions and not due to confounding. Since the aim of this study has been focussed on general trends such interactions have not yet been studied in detail.

\section{DISCUSSION}

The results of both - independent - studies thus consistently show that high variability of flexible working hours, both with regard to the duration and the chronological position, especially if company controlled, is clearly associated with increased impairments in health and well being. Flexible working hours therefore have to be considered against such detrimental effects to health and well being, even if on the other hand there are also some positive effects, as might be expected, from gaining more autonomy over one's working conditions and being able to adapt one's working hours to personal preferences or needs. Variable, company controlled flexible working hours obviously are a risk to health, individual and psychosocial well being. Since fixed 'normal' working hours have not been included in both studies there is no possibility for estimating the risk against this reference group. However, taking the group with autonomy and no variability as a control instead, the risk appears to be substantial.

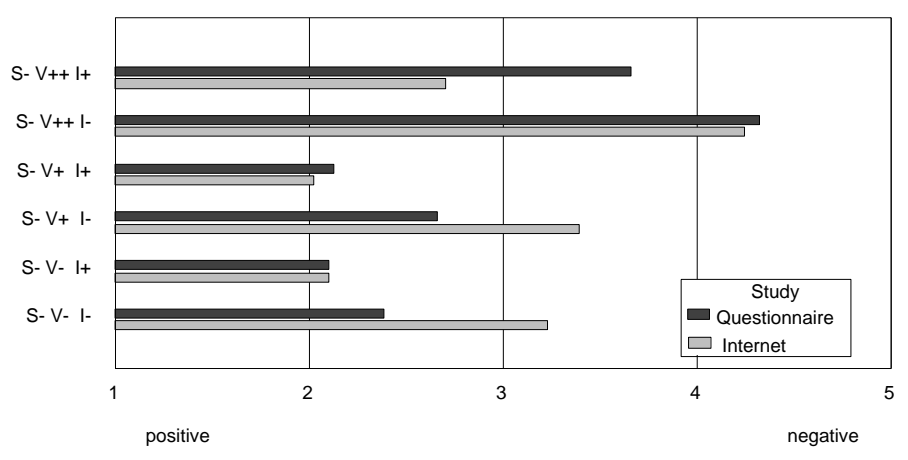

$\mathrm{S}=$ Shift work: $\mathrm{S}-=$ non shift workers [S+ = shift workers, not included here] $\mathrm{V}=$ level of variability: $\mathrm{V}-=$ no variability; $\mathrm{V}+=$ low variability; $\mathrm{V}++=$ high variability I = employee influence: $\mid-$ = no employee influence; $\mid+=$ = employee influence

Figure 2 - Perceived effects of flexible working hours on the leisure time by type of flexible working hours. 
Further analyses will therefore be conducted to get a more precise estimation of the risk, using different approaches for these analyses. One such approach might be a more differentiated use of more independent variables. This research used only a few questions on variability and autonomy to build a rather rough classification of flexible working hours systems. Using more items from the description of the individual systems might result in a more fine grained analysis, especially if combined with multiple or logistic regression approaches which would allow to make use of the total sample instead of concentrating on 'pure' types of flexibility. Another possibility might be canonical correlation analyses, since the results of the factor analyses showed that a reduction from observed to latent variables is quite effective on the side of the dependent variables. So a similar approach to the independent variables might also be promising in providing more detailed insight into the existing relations.

It should be noted, however, that the results presented here are in good agreement with those from other studies analyzing the effects of variability and autonomy in flexible working hours, using completely different approaches with completely different samples. ${ }^{1,47}$ Variability of working hours and the lack of autonomy in controlling these working hours - or stated differently: company controlled flexibility was also in these studies correlated with decreased well being. If such company controlled flexibility was associated with shift work, e.g. company controlled variable (or flexible) shift work this resulted in a further increase in physical and psychosocial impairments. This would mean that variability of working hours is the crucial variable, whether this variability is induced by 'normal' shift work, flexible working hours, or especially as a combination of both.

Autonomy seems to work as a buffer variable in this relationship. Those who are autonomously control- ling their flexible working hours consistently show less impairments, although autonomy does not compensate the effects of variability, and certainly not for those with high variability. This can either be a fact or an artefact. It should be remembered that such a result could be expected according to theories of cognitive dissonance ${ }^{6}$ or causal attribution: those who are in control of their working hours have to blame themselves for any negative effects. It could thus be that those have underreported their impairments - and those who are company controlled over reported impairments. This question, however, would have to be addressed by a different methodological approach, e.g. collecting data on independent and dependent variables from different sources, preferably from independent observations of working hours, their desynchronization with normal working hours, ${ }^{8}$ some index of physiological and psychosocial desynchronization and effect variables, in order to get a more complete picture of the assumed causal chain. But whatever the answer to this question will be, the effect of the variability of working hours will most probably remain.

This leads to the conclusion that recommendations for an appropriate design of flexible working hours should be developed in order to minimize any impairing effects on health and psychosocial well-being; these recommendations should include - besides allowing for discretion in controlling one's (flexible) working hours - that variability in flexible working hours should be kept low (or at least moderate), even if this variability is self-controlled. It might, however, be questionable whether this is what some of the proponents of flexible hours are asking for. If on the other hand variability is unavoidable it should be planned well ahead in order to provide reliability and a basis for planning for the employees, besides providing compensation which is suitable to avoid the impairing effects of an increased variability.

\section{REFEREN CES}

1. Bohnert $V$, Janssen $D, N$ achreiner F. Effects of flexible working hours on health and well being - results from a secondary analysis of a European survey. Shiftwork Int Newsl 2003;20:421.

2. Colquhoun WP, Costa G, Folkard F, Knauth P. Shiftwork: problems and solutions. Frankfurt: Peter Lang; 1996.

3. Costa G. Effects on health and wellbeing. In: Colquhoun P, Costa G, Folkard S, Knauth P, editors. Shiftwork: problems and solutions. Frankfurt: Peter Lang; 1996. p. 113-39.
4. Costa $G$, Akerstedt $T$, N achreiner F, Frings-D resen $F$, Folkard S, Gadbois $C$ et al. As time goes by - flexible work hours, health and well-being. Final report for SALTSA [CD-ROM]. Stockholm: National Institute for Working Life; 2003. (Working Life Research in Europe, 8).

5. Deinert K, Lenzing K, Nachreiner F. Zur Prävalenz flexibler Arbeitszeiten in der Bundesrepublik Deutschland. In: Gesellschaft für Arbeitswissenschaft EV editor. Arbeitswissenschaft im Zeichen gesellschaftlicher Vielfalt. $48^{\text {th }}$ Arbeitswissenschaftlicher Kongreß der GfA; 2002 feb 22; Linz, Germany. Dortmund: GfA-Press: 2002. p. 229-33. 
6. Festinger L. A theory of cognitive dissonance. Stanford, Cal.: Stanford University Press; 1957.

7. Folkard S. The impact of age and the flexibility of work hours on outcome measures. Shiftwork Int Newsl 2003;20:72.

8. Giebel $O$, Janssen $D$, Schomann $C, N$ achreiner $F . A$ new approach for evaluating flexible working hours. Shiftwork Int Newsl 2003;20:77.

9. Hedden I, Bonitz D, Grzech-Sukalo H, Nachreiner F. Zur Klassifikation und Analyse unterschiedlicher Schichtsysteme und ihrer psychosozialen Effekte. Teil 2: Differentielle Effekte bei Gruppierung nach periodischen Merkmalen - Überprüfung eines alternativen Klassifikationsansatzes. Z Arbeitswiss $1989 ; 43: 73-8$.

10. Janssen D, Nachreiner F. Differential psychosocial effects of different shift systems: a comparison of these effects of shiftwork under different systems in the chemical industry. Shiftwork Int Newsl 2001;18:10.
11. Janssen D, Nachreiner F. Flexible Arbeitszeiten. Bremerhaven: Wirtschaftsverlag NW; 2004.

12. Knauth $P$, Costa G. Psychosocial effects. In: Colquhoun P, Costa G, Folkard S, Knauth P, editors Shiftwork: problems and solutions. Frankfurt: Peter Lang; 1996. p. 89-112.

13. Lenzing $\mathrm{K}, \mathrm{N}$ achreiner $\mathrm{F}$. O $\mathrm{n}$ the prevalence of flexible working hours in Germany. Shiftwork $I n I$ Newsl 2001;18:23.

14. Nachreiner F. Time on task effects on safety. J Hum Ergol 2001;30:97-102.

15. Nachreiner F. Diversity and equity: dealing with biological and social differences. Shiftwork Int Newsl 2003;20:137.

16. Nachreiner F, Grzech-Sukalo, H. Flexible Formen der Arbeitszeit. In: Luczak H, Volpert W, Müller T, editors. Handbuch Arbeitswissenschaft. Stuttgart: Schäffer-Poeschel; 1997. p. 952-7. 